\title{
Molecular speciation and tissue compartmentation of zinc in durum wheat grains with contrasting nutritional status
}

Persson, Daniel Pergament; de Bang, Thomas C.; Pedas, Pai R.; Kutman, Umit Baris; Cakmak, Ismail; Andersen, Birgit; Finnie, Christine; Schjoerring, Jan K.; Husted, Søren

Published in:

New Phytologist

Link to article, DOI:

10.1111/nph.13989

Publication date:

2016

Document Version

Publisher's PDF, also known as Version of record

Link back to DTU Orbit

Citation (APA):

Persson, D. P., de Bang, T. C., Pedas, P. R., Kutman, U. B., Cakmak, I., Andersen, B., Finnie, C., Schjoerring, J. K., \& Husted, S. (2016). Molecular speciation and tissue compartmentation of zinc in durum wheat grains with contrasting nutritional status. New Phytologist, 211(4), 1255-1265. https://doi.org/10.1111/nph.13989

\section{General rights}

Copyright and moral rights for the publications made accessible in the public portal are retained by the authors and/or other copyright owners and it is a condition of accessing publications that users recognise and abide by the legal requirements associated with these rights.

- Users may download and print one copy of any publication from the public portal for the purpose of private study or research.

- You may not further distribute the material or use it for any profit-making activity or commercial gain

- You may freely distribute the URL identifying the publication in the public portal 


\section{Molecular speciation and tissue compartmentation of zinc in durum wheat grains with contrasting nutritional status}

\section{Daniel Pergament Persson ${ }^{1}$, Thomas C. de Bang ${ }^{1}$, Pai R. Pedas ${ }^{1}$, Umit Baris Kutman ${ }^{2}$, Ismail Cakmak ${ }^{2}$, Birgit Andersen $^{1}$, Christine Finnie ${ }^{3}$, Jan K. Schjoerring ${ }^{1}$ and Søren Husted ${ }^{1}$}

${ }^{1}$ Plant and Soil Science Section, Department of Plant and Environmental Sciences, Faculty of Science, University of Copenhagen, Thorvaldsensvej 40, Frederiksberg C DK-1871, Denmark;

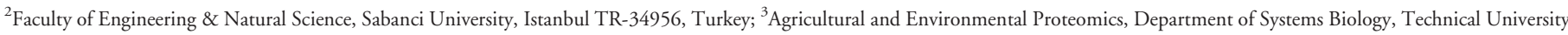
of Denmark, Building 301, Søltofts plads, Kongens Lyngby DK-2800, Denmark

Author for correspondence: Daniel Pergament Persson

Tel: +453533 3458

Email:dap@plen.ku.dk

Received: 9 November 2015

Accepted: 23 March 2016

New Phytologist (2016) 211: 1255-1265 doi: 10.1111/nph.13989

Key words: durum wheat, endosperm, inductively coupled plasma-mass spectrometry (ICP-MS), laser ablation (LA), speciation, zinc ( $Z n)$-binding proteins, zinc (Zn) localization.

\section{Summary}

- Low concentration of zinc $(Z n)$ in the endosperm of cereals is a major factor contributing to $\mathrm{Zn}$ deficiency in human populations. We have investigated how combined $\mathrm{Zn}$ and nitrogen (N) fertilization affects the speciation and localization of $\mathrm{Zn}$ in durum wheat (Triticum durum).

- Zn-binding proteins were analysed with liquid chromatography ICP-MS and Orbitrap MS ${ }^{2}$, respectively. Laser ablation ICP-MS with simultaneous $\mathrm{Zn}$, sulphur (S) and phosphorus (P) detection was used for bioimaging of $\mathrm{Zn}$ and its potential ligands.

- Increasing the $\mathrm{Zn}$ and $\mathrm{N}$ supply had a major impact on the $\mathrm{Zn}$ concentration in the endosperm, reaching concentrations higher than current breeding targets. The $\mathrm{S}$ concentration also increased, but $\mathrm{S}$ was only partly co-localized with $\mathrm{Zn}$. The mutual $\mathrm{Zn}$ and S enrichment was reflected in substantially more $\mathrm{Zn}$ bound to small cysteine-rich proteins (apparent size $10-30 \mathrm{kDa}$ ), whereas the response of larger proteins (apparent size $>50 \mathrm{kDa}$ ) was only modest. Most of the $\mathrm{Zn}$-responsive proteins were associated with redox- and stress-related processes.

- This study offers a methodological platform to deepen the understanding of processes behind endosperm $\mathrm{Zn}$ enrichment. Novel information is provided on how the localization and speciation of $\mathrm{Zn}$ is modified during $\mathrm{Zn}$ biofortification of grains.

\section{Introduction}

Zinc $(\mathrm{Zn})$ deficiency is one of the main threats to human health, affecting c. $30 \%$ of the world's population (Hotz \& Brown, 2001; Gibson etal., 2008; Bouis \& Welch, 2010; White \& Broadley, 2011; Gibson, 2012). The deficiency is particularly pronounced in human populations depending on cereal and legume-based diets due to the inherent low concentration and bioavailability of $\mathrm{Zn}$ in these food staples (Gibson, 2012). The main strategies to alleviate $\mathrm{Zn}$ deficiency embrace supplementation, food fortification and biofortification (Garcia-Banuelos et al., 2014). Biofortification, both via genetically improved crops or by agronomic strategies, aims at increasing the $\mathrm{Zn}$ content of edible plant parts and is considered to be the most long-term sustainable and cost-efficient strategy to combat $\mathrm{Zn}$ malnutrition (Bouis \& Welch, 2010). However, in order to reach the full potential of biofortification with essential micronutrients, improved understanding of the processes involved in transport, storage and bioavailability of these elements in the various tissue compartments of the cereal grain is required (Garcia-Banuelos et al., 2014).
The $\mathrm{Zn}$ concentration in whole wheat grains is typically $c$. $25 \mathrm{\mu g} \mathrm{g}^{-1} \mathrm{DW}$ but can be considerably higher following $\mathrm{Zn}$ fertilization, especially in combination with an adequate nitrogen (N) supply, both under glasshouse (Kutman et al., 2010) and field conditions (Cakmak et al., 2010a). The latter reflects the fact that there is a positive correlation between grain protein and the content of not only $\mathrm{Zn}$, but also other important micronutrients such as iron (Fe) and manganese (Mn) (Zhao et al., 2009; Cakmak et al., 2010b; Kutman et al., 2010). Increases in grain $\mathrm{Fe}$ by increasing the $\mathrm{N}$ nutritional status of plants have been also shown in wheat (Aciksoz et al., 2011).

It is a well-established fact that cereal grains, including wheat, have a heterogeneous distribution of essential trace elements (Lombi et al., 2011; Kyriacou et al., 2014). Their concentrations are typically much higher in the outer parts of the grain than in the core endosperm, although in rice and barley $\mathrm{Zn}$ appears to be less strictly confined to the outer layers than, for example, Fe and Mn (Hansen et al., 2009; Lombi et al., 2011). Nevertheless, the losses of $\mathrm{Zn}$ in wheat upon milling are typically 30-40\% (Kutman etal., 2011) and efficient loading of essential trace elements into the core endosperm is therefore crucial. 
In the aleurone cells and embryo, $\mathrm{Zn}$ and other micronutrients are largely co-localized with inositol hexakisphosphate-6 (InsP $\mathrm{P}_{6}$; phytic acid). This has been taken as evidence that $\mathrm{Zn}-\mathrm{Ins} \mathrm{P}_{6}$ complexes are the main molecular species of $\mathrm{Zn}$ in cereal grains (Lott et al., 2000; Gibson et al., 2010). The inhibitory effect of $\operatorname{InsP}_{6}$ on $\mathrm{Zn}$ adsorption in the human gut has promoted this assumption (Hunt, 2003; Lonnerdal etal., 2006). However, several recent studies have shown that $\mathrm{Zn}$ in cereal grains is associated with proteins rather than with phytic acid (Persson et al., 2009; Kutman et al., 2010; Lombi et al., 2011; Kyriacou et al., 2014). This is especially the case in the endosperm which has a very low concentration of phytic acid (Velu et al., 2014).

A range of state-of-the art analytical techniques have been employed to investigate the localization and speciation of $\mathrm{Zn}$ and other essential trace elements in cereal grains. However, analytical limitations caused by inadequate sensitivity have restricted the progress with respect to ion loading and speciation in the endosperm. X-ray fluorescence and absorption techniques have been used to study $\mathrm{Fe}$ and $\mathrm{Zn}$ coordination in aleurone cells of barley and wheat (Lombi et al., 2011; Neal et al., 2013); however, the detection limits for $\mathrm{Fe}$ and $\mathrm{Zn}$ did not allow for analysis of this coordination in the endosperm. Moore et al. (2012) used highresolution nano-secondary ion mass spectrometry (nano-SIMS) to show how $\mathrm{Fe}$ and phosphorus $(\mathrm{P})$ were localized in the aleurone and in the outer endosperm (i.e. the subaleurone) of mature wheat grains. Unfortunately, $\mathrm{Zn}$ has an inherently low sensitivity in nano-SIMS and was for this reason not included in this analysis (Moore et al., 2012). Wheat grains were recently investigated by X-ray fluorescence microscopy (XRF), showing an enrichment in endosperm $\mathrm{Zn}$ concentrations upon foliar fertilization (Ajiboye et al., 2015). Compared with X-ray based techniques, state-ofthe-art laser ablation-inductively coupled plasma-mass spectrometry (LA-ICP-MS) has slightly lower resolution, but offers higher sensitivity and also allows for isotope ratio measurements without compromising the multi-elemental capacity (Becker et al., 2008). By using LA-ICP-MS it has been shown in grains of wheat plants grown under field conditions that $\mathrm{Zn}$ is transported into endosperm through the crease phloem (Cakmak et al., 2010a).

The identity of the quantitatively most important $\mathrm{Zn}$-binding ligands, including proteins, remains unclear. Molecular speciation analysis, using hyphenation of liquid chromatography (LC) with ICP-MS techniques (LC-ICP-MS), has been employed previously to show that nicotianamine (NA) and deoxymugeinic acid (DMA) were the main $\mathrm{Zn}$-binding ligands in the endosperm of grains from rice plants overexpressing nicotianamine synthase (NAS) genes (Lee et al., 2009, 2011). However, no intact $\mathrm{Zn}-\mathrm{NA}$ or $\mathrm{Zn}-$ DMA complexes have so far been identified in the endosperm of wild-type plants. Moreover, a range of other proteins and enzymes that potentially may bind Zn (DuPont et al., 2005; Vensel et al., 2005) have been identified in cereal grain tissues, but in vivo confirmation of their existence as metal-complexes (metalloproteins) has never been achieved experimentally.

The objective of the present study was to analyse and quantify the combined effects of $\mathrm{Zn}$ and $\mathrm{N}$ fertilization on the molecular speciation and tissue compartmentation of $\mathrm{Zn}$. Durum wheat grains were used as the biological case, and were analysed by the combined use of LA-ICP-MS, LC-ICP-MS and Q-Exactive Orbitrap $\mathrm{MS}^{2}$. Along with detailed whole-grain bioimaging of $\mathrm{Zn}, \mathrm{S}$ and $\mathrm{P}$ - the latter two elements being proxies for proteins and phytic acid, respectively - we have identified a group of putative $\mathrm{Zn}$-binding proteins in the endosperm, which respond to combined $\mathrm{Zn}$ and $\mathrm{N}$ fertilization treatments.

\section{Materials and Methods}

\section{Soil and plant materials}

Durum wheat (Triticum durum L. cv Balcali 2000) plants were grown in soil-filled pots $(3.1 \mathrm{~kg}$ soil per pot) in a glasshouse at Sabanci University (Istanbul, Turkey). The soil was from a semiarid region of Central Anatolia (Sultanonu, Eskisehir), and was severely Zn-deficient, calcareous (18\% calcium carbonate) and with a high $\mathrm{pH}(\mathrm{pH}=8.0$ in MilliQ water; Milli-Q Plus, Millipore). It had a clayey texture and was very low in organic matter (1.5\%). The diethylenetriaminepentaacetic acid (DTPA)extractable $\mathrm{Zn}$ concentration was $0.13 \mathrm{mg} \mathrm{kg}^{-1}$, which is considered to be below the critical threshold for plant-available $\mathrm{Zn}$. The plants were supplied with two different concentrations of $\mathrm{N}$ (low and high) via soil applications and three different concentrations of $\mathrm{Zn}$ (low, medium and high) via soil and foliar applications. The experiment had a completely randomized design with three pot replicates per treatment. Before sowing, $100 \mathrm{mg} \mathrm{P} \mathrm{kg}^{-1}$ soil as $\mathrm{KH}_{2} \mathrm{PO}_{4}$ and $25 \mathrm{mg} \mathrm{S} \mathrm{kg}{ }^{-1}$ soil as $\mathrm{K}_{2} \mathrm{SO}_{4}$ were added to each pot. Each pot also received different concentrations of $\mathrm{N}$ as $\mathrm{Ca}$ $\left(\mathrm{NO}_{3}\right)_{2} \cdot 4 \mathrm{H}_{2} \mathrm{O}: 50 \mathrm{mg} \mathrm{N} \mathrm{kg}^{-1}$ soil for the low-N (LN) and $100 \mathrm{mg} \mathrm{N} \mathrm{kg}^{-1}$ soil for the high- $\mathrm{N}(\mathrm{HN})$ treatments. The high$\mathrm{N}$ plants received three additional $\mathrm{N}$ applications, each amounting to $100 \mathrm{mg} \mathrm{N} \mathrm{kg}^{-1}$ soil, at the booting, anthesis and milk stages. Consequently, the low- $\mathrm{N}$ and high- $\mathrm{N}$ plants were in total supplied with 50 and $400 \mathrm{mg} \mathrm{N} \mathrm{kg}^{-1}$ soil, respectively.

$\mathrm{Zn}$ was added as $\mathrm{ZnSO}_{4} \cdot 7 \mathrm{H}_{2} \mathrm{O}$, as follows: $0.5 \mathrm{mg} \mathrm{Zn} \mathrm{kg}^{-1}$ soil for the low-Zn (LZn) and $5.0 \mathrm{mg} \mathrm{Zn} \mathrm{kg}^{-1}$ soil for the medium-Zn $(M Z n)$ treatments. Plants in the high- $Z n$ treatment $(\mathrm{HZn})$ also received $5.0 \mathrm{mg} \mathrm{Zn} \mathrm{kg}^{-1}$ soil as in the MZn treatment, but additionally were supplied with $\mathrm{Zn}$ by foliar application $\left(0.2 \% \mathrm{w} / \mathrm{v} \mathrm{ZnSO}_{4} \cdot 7 \mathrm{H}_{2} \mathrm{O}\right.$ and $0.01 \% \mathrm{w} / \mathrm{v}$ Tween-20) at the booting, anthesis and milk stages. The total supply of $\mathrm{S}$ was $c$. 27.5 and $25.25 \mathrm{mg} \mathrm{S}$ in the MZn and LZn treatments, respectively, whereas the $\mathrm{HZn}$ treatments received more $S$ from the foliar applications than both the $\mathrm{LZn}$ and the MZn treatments.

The dried grains were weighed before the embryo was removed with a scalpel. The rest of the grain was polished by shaking with sand in 2-ml Eppendorf tubes mounted in racks on a MM301 Retsch mixer mill (Retsch, Haan, Germany). Each tube contained five grains and $600 \mathrm{mg}$ of acid-washed quartz sand. The polishing removed c. $25 \%$ of the dry matter from the embryofree grains. The abraded material, consisting of the outer grain layers, was collected together with the sand. Tubes filled only with sand were included in order to make sure that no plastic was abraded from the inside of the Eppendorf tube. This was not the case. Finally, the remaining part of the grain, the endosperm, was collected; this fraction was also used for the speciation analyses. 
Analysis of total element concentrations by ICP-OES and ICP-MS

Grain samples $(0.3-0.4 \mathrm{~g})$ were digested by using $2 \mathrm{ml}$ of $3 \%$ hydrogen peroxide $\left(\mathrm{H}_{2} \mathrm{O}_{2}\right)$ and $5 \mathrm{ml}$ of $65 \% \mathrm{HNO}_{3}$ per sample in a closed-vessel microwave system (MarsExpress; CEM Corp., Matthews, NC, USA). Inductively coupled plasma optical emission spectrometry (ICP-OES, Vista-Pro Axial; Varian Pty Ltd, Mulgrave, Vic., Australia) was used to determine the Zn, Fe, P and $\mathrm{S}$ concentrations in the digests. The total $\mathrm{N}$ concentration of grain samples was measured by using a LECO TruSpec C/N Analyzer (Leco Corp., St Joseph, MI, USA).

The separated grain tissues (embryo, endosperm and outer layers) were digested with $70 \% \mathrm{HNO}_{3}$ in a microwave oven. The digests were analysed on an ICP-MS (Agilent 7500ce, Agilent Technologies, Manchester, UK) equipped with a micro-flow nebulizer (Burgener AriMist HP, Analytical West Inc., Corona, CA, USA), an octopole reaction system (ORS) and a mass flow controller enabling $\mathrm{He} / \mathrm{O}_{2}$ flow rates from 0.1 to $1 \mathrm{ml} \mathrm{min}^{-1}$. Addition of oxygen $\left(0.5 \mathrm{ml} \mathrm{min}^{-1}\right)$ allowed simultaneous analysis of ${ }^{32} \mathrm{~S}\left(\right.$ as $\left.{ }^{48} \mathrm{SO}^{+}\right),{ }^{56} \mathrm{Fe}\left(\right.$ as $\left.{ }^{72} \mathrm{FeO}^{+}\right),{ }^{31} \mathrm{P}\left(\right.$ as $\left.{ }^{47} \mathrm{PO}^{+}\right),{ }^{66} \mathrm{Zn},{ }^{63} \mathrm{Cu}$, ${ }^{55} \mathrm{Mn}$ and ${ }^{60} \mathrm{Ni}$, as described in Persson et al. (2009). An HPLC (UltiMate 3000, Thermo Fisher Scientific) was used as auto sampler, injecting $50 \mu \mathrm{l}$ per sample and using nitric acid (3.5\%) as mobile phase. All sample batches included the use of certified durum wheat reference material (Reference Material 8436; National Institute of Standards and Technology (NIST), Gaithersburg, MD, USA). All dilutions, solutions and wash procedures were made with Milli-Q element water.

\section{LA-ICP-MS analysis of grains}

Individual grains were embedded in Spurr's resin, which was prepared according to the following procedure: $2.5 \mathrm{~g}$ of vinylcyclohexene (ERL) was weighed directly in a $10-\mathrm{ml}$ glass vial. Then, $6.5 \mathrm{~g}$ of nonenyl succinic anhydride (NSL) was added followed by $1.5 \mathrm{~g}$ of diglycidyl ether of polypropyleneglycol DER 736 (DER). These chemicals were briefly mixed before $0.1 \mathrm{~g}$ of dimethylaminoethanol (DMAE) was added. The resin was poured into a rubber mould, where the position of the individual grains was fixed with a needle, followed by drying at $60^{\circ} \mathrm{C}$ for $3 \mathrm{~d}$. When hardened, the grains were sliced on a microtome.

The LA-ICP-MS analyses were conducted with a nanosecond LA unit (NWR 193; New Wave Research, Fremont, CA, USA) equipped with an $\mathrm{ArF}$ excimer laser source operating at $193 \mathrm{~nm}$ using the following settings: energy: $5.8 \mathrm{~J} \mathrm{~cm}^{-2}$, scan speed: $80 \mu \mathrm{m} \mathrm{s}^{-1}$, repetition rate: $60 \mathrm{~Hz}$ and spot size $35 \mu \mathrm{m}$. The elemental detection was conducted on an Agilent 7500ce ICP-MS operated in standard (no gas) mode. The key parameters on the ICP-MS were: RF power: $1500 \mathrm{~V}$, sample depth: $5.5 \mathrm{~mm}$ and carrier gas flow: $1.01 \mathrm{~min}^{-1}$. The isotopes analysed were ${ }^{13} \mathrm{C}$ (int.time $0.01 \mathrm{~s}$ ), ${ }^{31} \mathrm{P}$ (int.time $0.02 \mathrm{~s}$ ), ${ }^{34} \mathrm{~S}$ (int.time $0.1 \mathrm{~s}$ ), ${ }^{55} \mathrm{Mn}$ (int. time $0.05 \mathrm{~s}$ ), ${ }^{56} \mathrm{Fe}$ (int. time $0.1 \mathrm{~s}$ ), ${ }^{63} \mathrm{Cu}$ (int.time $0.1 \mathrm{~s}$ ) and ${ }^{66} \mathrm{Zn}$ (int.time $0.1 \mathrm{~s}$ ). Six grains, each representing the different treatments, were aligned so that each line scan traversed all the grains. Hence, any change or drift in ICP-MS sensitivity affected all the treatments in the same way.

\section{SEC-ICP-MS analysis}

For speciation analyses, $100 \mathrm{mg}$ of endosperm powder was extracted using a pestle in an acid-washed mortar containing $200 \mathrm{mg}$ of acid-washed quartz sand and $2 \mathrm{ml}$ of $100 \mathrm{mM}$ ammonium acetate $(\mathrm{pH} 7.5)$. All extractions were performed on ice for $30 \mathrm{~min}$; homogenizing the extracts every $5 \mathrm{~min}$. The crude extract was centrifuged at $10000 \mathrm{~g}$ for $25 \mathrm{~min}$ at $4^{\circ} \mathrm{C}$ and the supernatant was decanted and filtered, first through a $0.45 \mu \mathrm{m}$ filter (Millipore) and then through a $100 \mathrm{kDa}$ ultra filter (Amicon 100; Millipore).

The analytical Size Exclusion Chromatography (SEC) column was a Biobasic SEC $120(300 \times 7.8 ; 5 \mu \mathrm{m}$ particle size, $120 \AA$ pore size; Thermo Fisher Scientific, Waltham, MA, USA) mounted with a pre-column (Biobasic SEC 120 pre-column; Thermo Fisher Scientific). The Biobasic SEC column was composed of deactivated $5 \mu \mathrm{m}$ silica coated with a hydro-link polymer to reduce the impacts of secondary ionic or hydrophobic interactions. All liquid chromatography was performed on an HPLC (UltiMate 3000) equipped with a DAD detector. All connections were of PEEK material with an internal diameter of $150 \mu \mathrm{m}$ (nanoViper, Dionex; Thermo Fisher Scientific). For molecular speciation analyses, the outlet from the DAD detector was connected to an ICP-MS (Agilent 7500ce ICP-MS; Agilent Technologies) operated in oxygen mode, as described earlier. The SEC-column was size-calibrated with the following mixture of standard metallo-proteins; ferritin $(\mathrm{Fe})(382 \mathrm{kDa})$, superoxide dismutase $(\mathrm{Cu} / \mathrm{Zn})(32 \mathrm{kDa})$, myoglobin $(\mathrm{Fe})(17 \mathrm{kDa})$ and vitamin $\mathrm{B} 12(\mathrm{Co})$ (cyanocobalamin; $1.3 \mathrm{kDa}$ ), all purchased from Sigma-Aldrich.

\section{Protein identification}

Ten micrograms of sample, lyophilized from ammonium acetate, was dissolved in urea $(8 \mathrm{M})$ and $50 \mathrm{mM}$ Tris- $\mathrm{HCl}(\mathrm{pH} 8.0)$. Reduction with DTT was carried out for $45 \mathrm{~min}$ at room temperature, at a final concentration of $40 \mathrm{mM}$. This was followed by alkylation with freshly dissolved iodoacetamide for $1 \mathrm{~h}$ at room temperature in the dark at a final concentration of $80 \mathrm{mM}$. The urea concentration was lowered to $1.6 \mathrm{M}$ with $10 \mathrm{mM}$ $\mathrm{NH}_{4} \mathrm{HCO}_{3}$ buffer, and $0.2 \mu \mathrm{g}$ Trypsin was added, followed by incubation at $37^{\circ} \mathrm{C}$ overnight. Hereafter, the sample was acidified by adding trifluoroacetic acid (TFA) to $0.2 \%(\mathrm{v} / \mathrm{v})$.

Stage Tip columns were made using DL-10 Diamond tips (Gilson Inc., Middleton, WI, USA) and C18 3M Empore Solid phase Extraction Disks (Sigma-Aldrich). The column was equilibrated with $0.1 \%$ TFA and the peptides loaded and washed with $0.1 \%$ TFA followed by elution with $80 \%$ acetonitrile $(\mathrm{ACN})$, $0.1 \%$ TFA. Eluted peptides were then dried in a vacuum centrifuge and redissolved in $0.5 \%$ formic acid, giving a peptide concentration of $0.1 \mu \mathrm{g} \mu \mathrm{l}^{-1}$.

Peptides $(0.5 \mu \mathrm{g})$ were separated on a nanoLC column (Acclaim PepMap 100 pre-column, $2 \mathrm{~cm} \times 75 \mu \mathrm{m}$ ID, nanoViper, $\mathrm{C} 18,3 \mu \mathrm{m}, 100 \AA$ pore size) combined with an 
Easy-spray column $(15 \mathrm{~cm} \times 50 \mu \mathrm{m}$ ID, PepMap C18, $>2 \mu \mathrm{m}$ particles, $100 \AA$ pore size analytical column, Thermo Fisher Scientific) using a $60 \mathrm{~min}$ gradient prepared from Solvent A $(0.1 \% \mathrm{FA})$ and $\mathrm{B}(80 \% \mathrm{ACN}$ in $0.1 \% \mathrm{FA})$, at a flow rate of $300 \mathrm{nl} \mathrm{min}^{-1}$ on an EASY nanoLC1000 coupled to a Q Exactive Orbitrap mass spectrometer (Thermo Fisher Scientific). The gradient was ramped from 5 to $50 \%$ of solvent $B$ in $40 \mathrm{~min}$ and then increased to $100 \%$ of solvent B for $10 \mathrm{~min}$. The Q Exactive was operated in data dependent mode with $10 \mathrm{MS}^{2}$ spectra for every full scan. The obtained $\mathrm{MS}^{2}$ spectra were processed using XCALIBUR v.2.0 (Thermo Fisher Scientific), analysed and searched using Mascot Daemon v.2.2.0 (Matrix Science) in the NCBInr green plants protein database. The applied search parameters were: one missed trypsin cleavage; allowed modifications: carbamidomethylated cysteine (fixed); oxidation of methionine (partial); peptide mass and $\mathrm{MS}^{2}$ tolerances were $5 \mathrm{ppm}$ and $0.4 \mathrm{Da}$ respectively.

Proteins in the SEC-fractions were accepted as reliable identifications if they met one of the following two criteria: detection of at least two top rank peptides with $P<0.05$ of which at least one was of first time use; a single top ranking peptide of first time use with $P<0.01$ and a minimum peptide length of 10 amino acids. For target $P$ predictions of cellular location (Emanuelsson et al., 2000), only results with reliability classes 1 and 2 were included, where $\mathrm{C}$ indicates sequences containing a chloroplast transit peptide, $\mathrm{M}$ a mitochondrial targeting peptide, $\mathrm{S}$ a signal peptide and _ indicates any other location.

Proteins meeting these criteria in the size-separated $\mathrm{Zn}$ binding fractions (from the SEC-ICP-MS analysis) were considered $\mathrm{Zn}$-relevant if they had been associated previously with one of the following properties: Zn-binding capacity, activation or inhibition by $\mathrm{Zn}$, part of a $\mathrm{Zn}$-regulated redox system, or response to oxidative/heavy metal stress or involved in $\mathrm{Zn}$ hyperaccumulation.

\section{Results}

\section{Plant responses to changes in $\mathrm{N}$ and $\mathrm{Zn}$ supply}

The responses to $\mathrm{Zn}$ application were very strong in both the $\mathrm{LN}$ and $H N$ treatments, leading to a six- and seven-fold higher whole grain $\mathrm{Zn}$ concentration in the $\mathrm{HZn}-\mathrm{LN}$ and $\mathrm{HZn}-\mathrm{HN}$ treatments compared with the respective $\mathrm{LZn}$ treatments $(P<0.001$; Fig. 1). Grain $\mathrm{Zn}$ concentration increased strongly with $\mathrm{N}$ supply in the MZn and HZn treatments $(P<0.005$ and $P<0.001$, respectively), but not in the $\mathrm{LZn}$ treatment $(P>0.05)$. On average, grains had $33-43 \%$ higher $\mathrm{Zn}$ concentration in the $\mathrm{HN}$ treatments compared with the LN treatments. Grain yield and number of grains per plant were positively affected by application of $\mathrm{Zn}$ in combination with $\mathrm{N}(P<0.001)$, whereas grain weight was affected by $\mathrm{N}$ supply only (on average there was a $27 \%$ increase from LN to HN; Supporting Information Table S1).

$\mathrm{Zn}$ application also had a positive effect on the grain $\mathrm{S}$ concentration, but only in combination with a high $\mathrm{N}$ supply $(P<0.001$; Fig. 1). Comparison of the treatments $\mathrm{HN}-\mathrm{MZn}$ vs



Fig. 1 Zinc (Zn) and sulfur (S) concentrations in whole grains harvested from durum wheat plants supplied with different combinations of $Z n$ and nitrogen ( $N$ ). LN, low-N supply; HN, high-N supply; LZn, low-Zn supply; $M Z n$, medium-Zn supply; $\mathrm{HZn}$, high-Zn supply. The data were analysed using two-way ANOVA and the bars represent means \pm SD $(n=3)$. Letters above columns indicate statistically significant $(P<0.05)$ differences between the $L N$ and $H N$ treatments (first letter, A or B) and between the LZn, MZn and $\mathrm{HZn}$ treatments within the same $\mathrm{N}$ treatment (second letter; $\mathrm{a}, \mathrm{b}$ or $\mathrm{c}$ ).

$\mathrm{LN}-\mathrm{MZn}$ and $\mathrm{HN}-\mathrm{HZn}$ vs $\mathrm{LN}-\mathrm{HZn}$ both showed c. $73 \%$ increase in $S$ concentration $(P<0.001)$.

The grain $\mathrm{N}$ concentration increased, as expected, with $\mathrm{N}$ supply, but was not affected by concomitant $\mathrm{Zn}$ provision $(P>0.05$; Table S1). The $\mathrm{P}$ concentration also increased with $\mathrm{N}$ supply, being c. $20 \%$ higher in the HN compared with the LN treatments, but was not affected by the $\mathrm{Zn}$ treatments; hence, no $\mathrm{P}: \mathrm{Zn}$ antagonism was observed $(P>0.05$; Table $\mathrm{S} 2)$.

\section{Tissue separation and $\mathrm{Zn}$ analysis}

The durum wheat grains were mechanically separated into three distinct tissue types: embryo, bran and endosperm. Each fraction was weighed, digested and the elemental composition analysed by ICP-MS. Less than $2 \%$ of the material was lost in the separation process (data not shown). The recoveries for $\mathrm{Zn}$ were also acceptable, as they were within $\pm 10 \%$ of the total $\mathrm{Zn}$ in each grain (Table 1).

The MZn and HZn treatments had a very strong impact on endosperm $\mathrm{Zn}$, resulting in 5.5- (LN) to 7.5-fold (HN) higher $\mathrm{Zn}$ concentration relative to the $\mathrm{LZn}$ treatments. The $\mathrm{N}$ supply also had a strong impact on the endosperm $\mathrm{Zn}$ concentrations, leading to $90 \%$ higher endosperm $\mathrm{Zn}$ concentration in the $\mathrm{HN}-$ $\mathrm{MZn}$ than in the $\mathrm{LN}-\mathrm{MZn}$ treatment $(P<0.005)$. In the HZn treatments (with either $\mathrm{LN}$ or $\mathrm{HN}$ ), the corresponding increase in endosperm $\mathrm{Zn}$ concentration in going from $\mathrm{LN}$ to $\mathrm{HN}$ was 63\% $(P<0.001$; Table 1). The endosperm concentration of $\mathrm{Zn}$ was not affected by $\mathrm{N}$ application in the $\mathrm{LZn}$ treatment $(P>0.05)$. The $\mathrm{Zn}$ concentrations in the bran and embryo showed similar strong responses to both of the $\mathrm{Zn}$ treatments and the $\mathrm{N}$ treatment, as was the case for the endosperm (Table 1). 
Table 1 Zinc concentrations in embryo, bran and endosperm tissues from wheat grain

\begin{tabular}{|c|c|c|c|c|c|c|c|}
\hline \multirow[b]{2}{*}{ Treatment } & \multicolumn{2}{|c|}{ 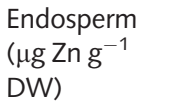 } & \multicolumn{2}{|c|}{$\begin{array}{l}\text { Bran } \\
\left(\mu g \text { Zn g }{ }^{-1}\right. \\
D W)\end{array}$} & \multicolumn{2}{|c|}{$\begin{array}{l}\text { Embryo } \\
\left(\mu g \text { Zn g }{ }^{-1}\right. \\
D W)\end{array}$} & \multirow{2}{*}{$\begin{array}{l}\text { Recovery } \\
(\%)\end{array}$} \\
\hline & Mean & SD & Mean & SD & Mean & $S D$ & \\
\hline $\mathrm{LN}-\mathrm{LZn}$ & 6.5 & $0.3^{\mathrm{Aa}}$ & 11.4 & $1.8^{\mathrm{Aa}}$ & 67.4 & $15.3^{\mathrm{Aa}}$ & 89.3 \\
\hline LN-MZn & 16.2 & $0.4^{\mathrm{Ab}}$ & 24.8 & $2.0^{\mathrm{Ab}}$ & 141.2 & $3.1^{\mathrm{Ab}}$ & 94.6 \\
\hline $\mathrm{LN}-\mathrm{HZn}$ & 36.2 & $2.0^{\mathrm{Ac}}$ & 65.3 & $14.0^{\mathrm{Ac}}$ & 193.1 & $26.4^{\mathrm{Ac}}$ & 103.2 \\
\hline $\mathrm{HN}-\mathrm{LZn}$ & 7.7 & $4.4^{\mathrm{Aa}}$ & 9.8 & $0.7^{\mathrm{Aa}}$ & 40.5 & $3.7^{\mathrm{Aa}}$ & 81.2 \\
\hline $\mathrm{HN}-\mathrm{MZn}$ & 30.8 & $6.2^{\mathrm{Bb}}$ & 66.2 & $12.8^{\mathrm{Bb}}$ & 154.6 & $1.7^{\mathrm{Bb}}$ & 99.8 \\
\hline $\mathrm{HN}-\mathrm{HZn}$ & 59.0 & $5.2^{\mathrm{BC}}$ & 124.1 & $31.6^{\mathrm{BC}}$ & 243.2 & $17.3^{\mathrm{BC}}$ & 100.7 \\
\hline
\end{tabular}

Data were analysed using a two-way ANOVA and are presented as means $\pm \mathrm{SD}(n=3)$. The recovery was calculated as the zinc ( $\mathrm{Zn})$ concentration multiplied with the DW for each of the three tissue fractions, added together and displayed as a percentage of the whole grain. Letters indicate statistically significant $(P<0.05)$ differences between the low- and highnitrogen $(\mathrm{N})$ treatments (first letter, $\mathrm{A}$ or $\mathrm{B}$ ) and between the low-, medium- and high- $\mathrm{Zn}$ treatments within the same $\mathrm{N}$ treatment (second letter; $\mathrm{a}$, b or c). LN, low-N supply; HN, high-N supply; LZn, low-Zn supply; MZn, medium-Zn supply; HZn, high-Zn supply.

\section{Multi-elemental compartmentation analysis}

In order to provide a more detailed picture of the elemental distribution in the grains, LA-ICP-MS was used for multi-elemental bioimaging. $\mathrm{P}$ and $\mathrm{S}$ were used as proxies of the ligand type

(a)
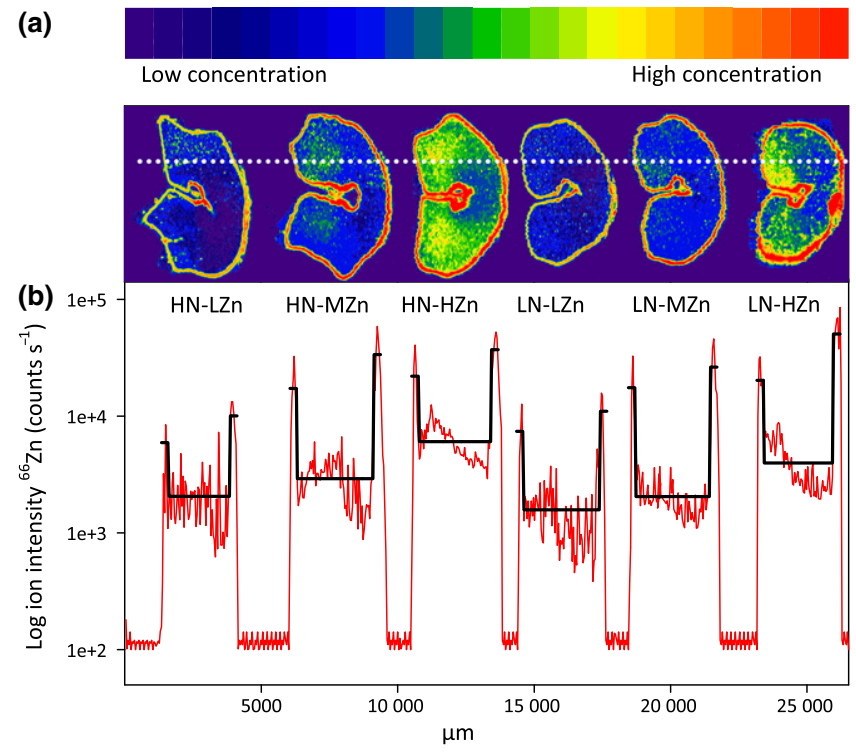

Fig. 2 (a) Distribution of ${ }^{66} \mathrm{Zn}$ in cross-sections of durum wheat grains harvested from plants supplied with different combinations of zinc ( $\mathrm{Zn}$ ) and nitrogen $(\mathrm{N})$. Elemental images were obtained using laser ablationinductively coupled plasma-mass spectrometry (LA-ICP-MS). The log ion intensity is displayed as a heat map where the red colour represents the highest intensity and the purple colour the weakest intensity. (b) The red line represents a line scan across all the six grains, corresponding to the white, dotted line in (a), where each grain represent one of the six N/Zn treatments. LN, low-N supply; HN, high-N supply; LZn, low-Zn supply; MZn, medium-Zn supply; HZn, high-Zn supply. The solid, black lines represent the mean of five line scans taken from the area represented by the dotted line in (a). because these elements are components of inositol phosphates (Ins $\mathrm{P}_{2}-\mathrm{Ins}_{6}$ ) and $\mathrm{Cys} / \mathrm{Met}$ containing proteins, respectively. The crease region had the strongest ${ }^{66} \mathrm{Zn}$ intensity in all treatments, followed by the outer layers (pericarp), including the aleurone layer (Fig. 2a). In all cases the core endosperm had the lowest ${ }^{66} \mathrm{Zn}$ ion intensities out of the three tissue types. $\mathrm{Zn}$ supply increased the ${ }^{66} \mathrm{Zn}$ signal in all tissue types, including the endosperm (Fig. 2a).

A line scan extending from the outer bran layer on the left (ventral) side to the outer bran layer on the right (dorsal) side of a grain, crossing the mineral-dense aleurone layer, the protein-rich subaleurone layer and the starchy endosperm tissues, revealed the existence of steep $\mathrm{Zn}$ gradients (Fig. $2 \mathrm{~b}$ ). In all treatments, the ${ }^{66} \mathrm{Zn}$ signal decreased five- to 10 -fold immediately adjacent to the bran layers.

The endosperm $\mathrm{Zn}$ enrichment of grains from the MZn and $\mathrm{HZn}$ treatments was observed mainly in the first third of the line scan (Fig. 2b). Thus, the endosperm $\mathrm{Zn}$ concentration was systematically higher in the ventral (crease) side of the grain compared with the dorsal side (left-hand vs right-hand side in Fig. 2a, b). The $\mathrm{Zn}$ enrichment of the ventral endosperm relative to the dorsal was as high as $60 \%$ in the HZn grains. By contrast, the outer grain layers contained on average a $\mathrm{Zn}$ concentration at the dorsal side twice that of the ventral side (for each individual grain compare the final $\mathrm{Zn}$ intensity on the right-hand side of the line scan with the initial $\mathrm{Zn}$ intensity on the left-hand side in Fig. $2 \mathrm{~b}$ ).

(a)

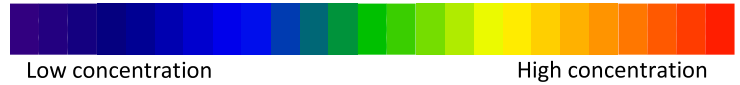

(b)
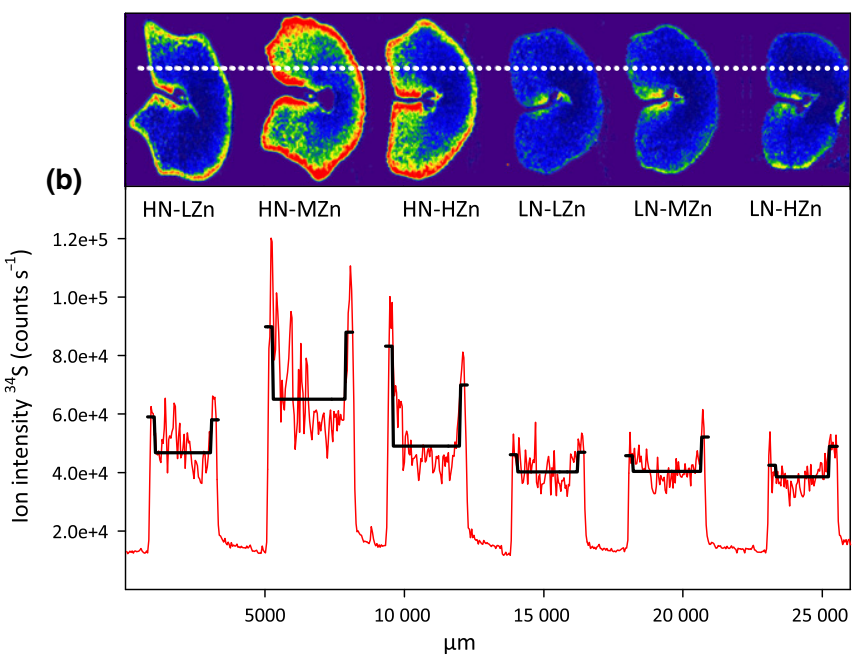

Fig. 3 (a) Distribution of ${ }^{34} \mathrm{~S}$ in cross-sections of durum wheat grains harvested from plants supplied with different combinations of zinc ( $\mathrm{Zn}$ ) and nitrogen $(\mathrm{N})$. Elemental images were obtained using laser ablationinductively coupled plasma-mass spectrometry (LA-ICP-MS). The ion intensity is displayed as a heat map where the red colour represents the highest intensity and the purple colour the weakest intensity. (b) The red line represents a line scan across all the six grains, corresponding to the white, dotted line in (a), where each grain represents one of the six N/Zn treatments. LN, low-N supply; HN, high-N supply; LZn, low-Zn supply; MZn, medium-Zn supply; HZn, high-Zn supply. The solid, black lines represent the mean of five line scans taken from the area represented by the dotted line in (a). 
The application of $\mathrm{ZnSO}_{4}$ in the $\mathrm{Zn}$ treatments did not affect the grain $S$ concentration in the LN treatments. However, in the $\mathrm{HN}$ treatments a substantial increase in the grain $S$ concentration occurred (Figs 1, 3a), and just like for $\mathrm{Zn}$, the ventral side of the endosperm contained substantially more $S$ than the dorsal side of the $\mathrm{HN}$ grains (Fig. $3 \mathrm{~b}$ ). In contrast to $\mathrm{Zn}$, the $S$ content of the ventral outer layers was higher than the dorsal outer layers, especially in the $\mathrm{HN}-\mathrm{MZn}$ and $\mathrm{HN}-\mathrm{HZn}$ treatments (Fig. 3b).

A comparison of the ${ }^{66} \mathrm{Zn},{ }^{31} \mathrm{P}$ and ${ }^{34} \mathrm{~S}$ distribution in the $\mathrm{HN}-\mathrm{HZn}$ grain revealed that the strongest ${ }^{66} \mathrm{Zn}$ signal occurred in the aleurone layer and co-lozalized with that of ${ }^{31} \mathrm{P}$ (Fig. 4). The ${ }^{31} \mathrm{P}$ signal was strictly confined to the aleurone layer with a very steep gradient towards the endosperm. Zinc, however, was not solely confined to the aleurone layer, but was present throughout the endosperm where it peaked in the first third of the ventral endosperm (Fig. 2b). The ${ }^{34} S$ signal was strongest just inside the aleurone layer, representing the protein-rich subaleurone layer. There was no clear correlation between $\mathrm{Zn}$ and $\mathrm{S}$ in the subaleurone layer; however, co-localization and mutual enrichment of $\mathrm{Zn}$ and $\mathrm{S}$ was seen in the ventral endosperm at $c$. 1300-1700 $\mu \mathrm{m}$ (Fig. 4).

\section{Zn speciation in the endosperm}

Extraction of endosperm tissue with a dilute salt buffer yielded the albumin and globulin proteins, which contained $22-26 \%$ of the total endosperm $\mathrm{Zn}$ (data not shown). Size separation of the biomolecules in this extract revealed two major $\mathrm{Zn}$-binding fractions appearing after 380-500 s ( $\mathrm{nn} \# 1)$ and 580-630 s (Zn\#2) in the chromatograms, corresponding to two distinct protein fractions with apparent molecular masses of $50-100 \mathrm{kDa}$ and $10-30 \mathrm{kDa}$, respectively (Fig. 5a). In both $\mathrm{Zn}$ fractions, co-elution with $S$ was evident, but substantially more $\mathrm{Zn}$ in the $\mathrm{Zn \# 2}$ fraction co-eluted with $S$ than in the $\mathrm{Zn \# 1}$ fraction (Fig. 5a,b). Neither Zn\#1 nor Zn\#2 showed any co-elution with



Fig. 4 Laser ablation-inductively coupled plasma-mass spectrometry (LAICP-MS) line scans showing the ${ }^{66} \mathrm{Zn},{ }^{34} \mathrm{~S}$ and ${ }^{31} \mathrm{P}$ signals from one side of the grain to the other. This particular grain was harvested from durum wheat plants supplied with high concentrations of zinc $(\mathrm{Zn})$ and nitrogen (N) ( $\mathrm{HN}-\mathrm{HZn}$ treatment).
$\mathrm{P}$, which mainly eluted after $500 \mathrm{~s}$ (data not shown), that is, between the two $\mathrm{Zn}$ fractions (Fig. 5a). Hence, there were no indications of $\mathrm{Zn}$ being associated with $\mathrm{Ins}_{6}$ or any other $\mathrm{P}$-containing ligands in the soluble part of the endosperm.

The $\mathrm{Zn}$ treatments had a profound effect on the $\mathrm{Zn}$ and $\mathrm{S}$ signals in the $\mathrm{Zn \# 2}$ fraction (Fig. 5a,b). In the HN-HZn treatment, $\mathrm{Zn \# 2}$ was 7.5 -fold higher than in the $\mathrm{HN}-\mathrm{LZn}$ treatment (Fig. 5a). The corresponding $S$ signal was approximately fourfold higher. In the $\mathrm{LN}$ treatments the increases in $\mathrm{Zn}$ and $\mathrm{S}$ in response to the increasing $\mathrm{Zn}$ supply were four-fold and 1.5-fold, respectively.

The strong impact of the combined N/Zn treatment on total endosperm $\mathrm{Zn}$ concentrations (Table 1) was mainly reflected in marked changes in the $\mathrm{Zn \# 2}$ fraction, whereas the $\mathrm{Zn \# 1}$ fraction was much less affected (Fig. 5a). Thus, there was $74 \%$ more $\mathrm{Zn}$ and c. 2.5-times more $S$ in the $\mathrm{Zn \# 2}$ endosperm fraction from $\mathrm{HN}-\mathrm{HZn}$ plants compared with $\mathrm{LN}-\mathrm{HZn}$ plants. Hence, the ratio between $\mathrm{Zn}$ and $\mathrm{S}$ changed markedly, resulting in 34\% more $\mathrm{S}$ per $\mathrm{Zn}$. The effect of HN and HZn supply on $\mathrm{Zn}$ and $\mathrm{S}$ in the $\mathrm{Zn \# 2}$ fraction was also reflected in the UV signals (Fig. 5c).

\section{Identification of $\mathrm{Zn}$-containing proteins}

The peak shapes of the two $\mathrm{Zn}$ fractions extracted from the endosperm were irregular, indicating that the fractions contained several different Zn-binding proteins (Fig. $5 \mathrm{a}-\mathrm{c}$ ). The identity of these putatively $\mathrm{Zn}$-binding proteins in the $\mathrm{HN}$ $\mathrm{HZn}$ grains was analysed with LC-Orbitrap based mass spectrometry. Indeed, a total of 218 proteins were identified consistently across biological replicates and analytical runs in the two

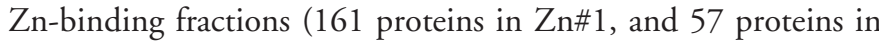


14 in $\mathrm{Zn \# 2}$ were considered of special interest with respect to $\mathrm{Zn}$; that is, they have previously been reported to be either $\mathrm{Zn}$ containing, $\mathrm{Zn}$-regulated and/or $\mathrm{Zn}$-responsive proteins (Tables S5, S6).

Most of the $\mathrm{Zn}$-related proteins in $\mathrm{Zn \# 1}$ belonged to the $\mathrm{C} / \mathrm{N}$ metabolism group, of which some were well-known $\mathrm{Zn}$-binding proteins. The stress/redox group was the second largest group, again with a few well-known $\mathrm{Zn}$-containing enzymes, for example $\mathrm{Cu} / \mathrm{Zn}$ superoxide dismutase (Tables S3, S5).

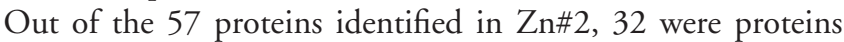
related to pathogen defence, mainly belonging to the group of alpha amylase inhibitors and nonspecific lipid transfer proteins. The redox/stress group was the second largest group, accounting for c. 25\% of the identified proteins (Tables S4, S6). Fourteen of the $\mathrm{Zn \# 2}$ proteins were considered to be $\mathrm{Zn}$-related, but there were only a few proteins with documented $\mathrm{Zn}$-binding properties (i.e. hydroxyacylglutathione hydrolase (glyoxalase II), protein disulphide isomerase (PDI), enolase and chitinase). Clearly, the largest group within the Zn-related proteins was the stress/redox group. In this group, Glutaredoxin, Cys-1 peroxiredoxin, thioredoxin also were identified, which are all cysteine-rich proteins involved in $\mathrm{Zn}$ - and S-related redox processes (Table S6). 


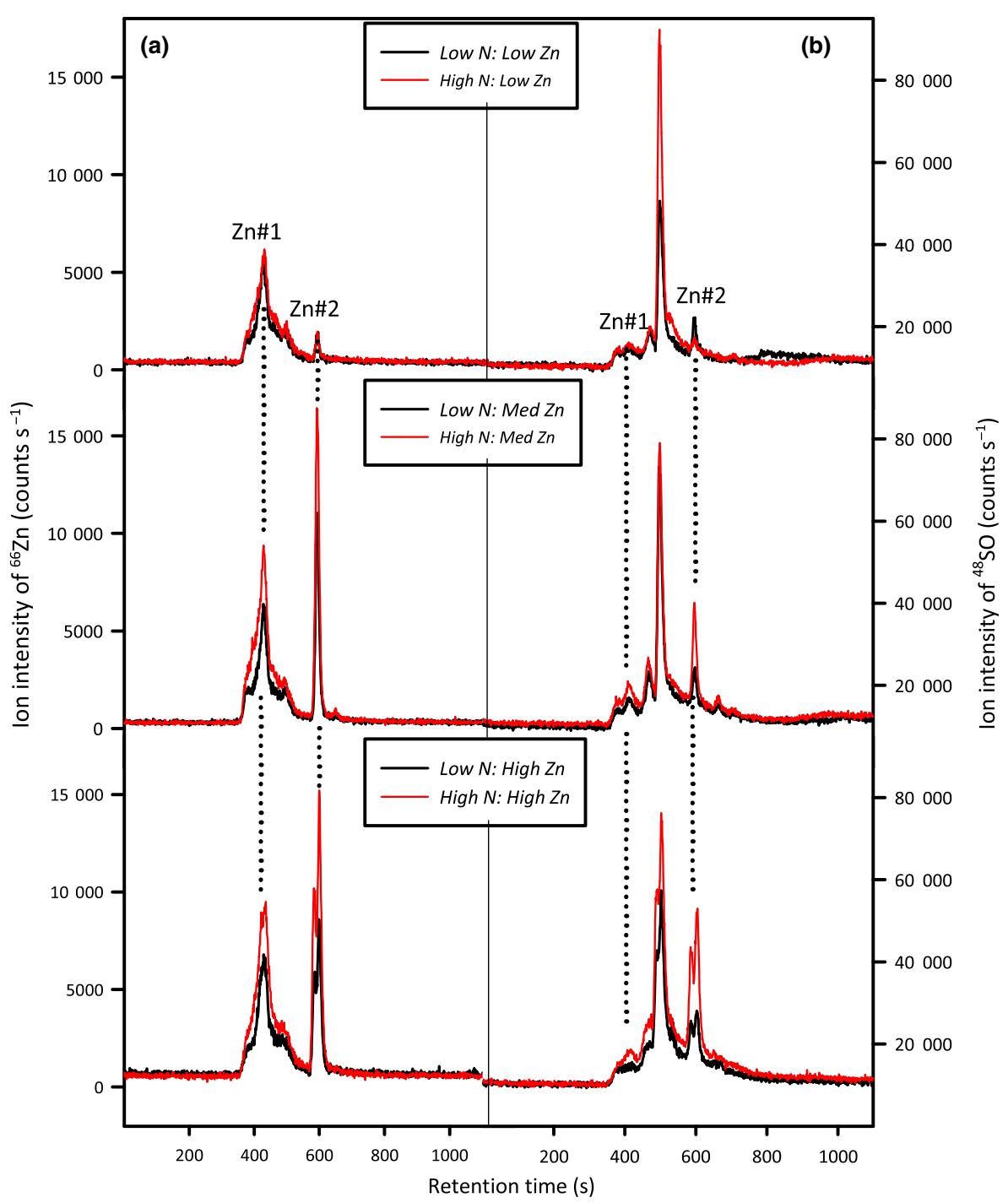

Fig. 5 Speciation chromatograms showing the distribution of (a) ${ }^{66} \mathrm{Zn}$ and (b) sulphur (S) (analysed as ${ }^{48} \mathrm{SO}$ ) containing compounds in dilute salt buffer extracts of endosperm from durum wheat grains. Grains were harvested from plants supplied with six different combinations of $\mathrm{Zn}$ and $\mathrm{N}$ and analysed by size exclusion chromatography-inductively coupled plasma-mass spectrometry (SECICP-MS). (c) Chromatogram from the same analysis, showing the UV signal at $254 \mathrm{~nm}$ (representing total protein) in grains from plants receiving low-N/low-Zn and high-N/ high-Zn supply. Zn\#1 corresponds to molecular weights of 50-100 kDa and Zn\#2 corresponds to molecular weights $10-30 \mathrm{kDa}$.

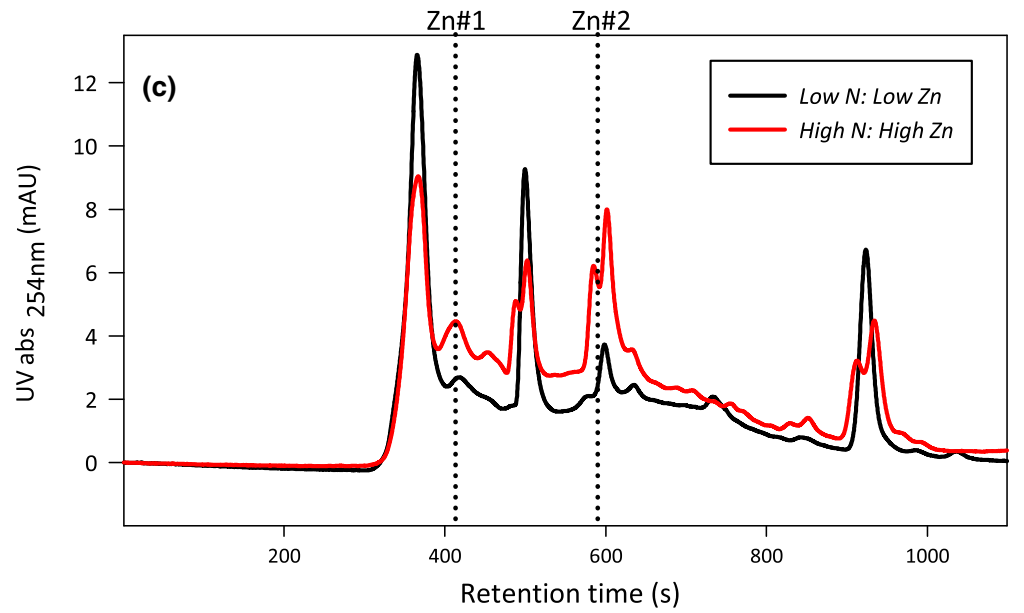

\section{Discussion}

Agronomic biofortification strategies like the one presented in this project may increase not only the zinc $(\mathrm{Zn})$ concentration in the whole grains but also in the endosperm. The achieved $\mathrm{Zn}$ concentrations in the endosperm (Table 1) were more than twice the breeding targets of $33 \mu \mathrm{gg}^{-1} \mathrm{DW}$ set up by HarvestPlus (Bouis \& Welch, 2010). Furthermore, the efficiency of $\mathrm{Zn}$ enrichment of the endosperm was clearly higher in combination with a high nitrogen $(\mathrm{N})$ supply as documented by the fact that the polished grains in the high-N-medium-Zn (HN-MZn) and $\mathrm{HN}-$ high-Zn $(\mathrm{HZn})$ treatments had 90 and 63\% higher 
endosperm concentration than the corresponding low-N (LN) treated plants (Table 1; see also Kutman et al., 2010). In agreement with these data, Kutman et al. (2011) reported up to sevenfold increases in endosperm $\mathrm{Zn}$ concentrations upon $\mathrm{Zn}$ fertilization and up to $80 \%$ increases upon higher $\mathrm{N}$ supply (comparing the same $\mathrm{Zn}$ treatment, but different $\mathrm{N}$ supply). The underlying biology of the strong interactions between $\mathrm{N}$ and $\mathrm{Zn}$ in terms of storage capacity for $\mathrm{Zn}$ in the endosperm remains largely unknown. However, endosperm proteins are considered as the major sink for $\mathrm{Zn}$, due to the low concentrations of phytate in the endosperm (Cakmak et al., 2010b; Velu et al., 2014).

\section{Zn loading to the grain}

Using stable isotope labelled Zn, Pearson et al. (1996) showed that $\mathrm{Zn}$ was delivered to the endosperm through the crease tissue during grain filling. Transport of $\mathrm{Zn}$ through the crease phloem into the endosperm of wheat grain has also been demonstrated by ablation-inductively coupled plasma-mass spectrometry (LAICP-MS) (Cakmak et al., 2010a). The transfer of $\mathrm{Zn}$ from the vascular bundles to the crease tissue, and from the transfer cells into the modified aleurone cells of the maternal endosperm tissue, seem to be the major bottlenecks for $\mathrm{Zn}$ enrichment (Pearson etal., 1996; Wang etal., 2011; Ajiboye etal., 2015). Especially upon foliar application during late grain filling, $\mathrm{Zn}$ seems to accumulate in the crease region, possibly as a result of these bottlenecks for $\mathrm{Zn}$ transfer from crease to endosperm, via the endosperm cavity (Ajiboye et al., 2015). Our results support this observation, albeit with less pronounced $\mathrm{Zn}$ accumulation in the vascular bundles and in the nucellar projection (Fig. S1). The presence of nicotianamine (NA) as Zn-binding ligand may facilitate transport into the endosperm (Lee et al., 2009; Wirth et al., 2009; Zheng et al., 2010). In support of this, YSL (yellow stripe like) and NAS (nicotianamine synthase) genes are highly expressed both in the transfer cells and in the modified aleurone cells in barley (Tauris et al., 2009). In the present work we did not observe strong co-localization of $\mathrm{Zn}$ and sulfur $(\mathrm{S})$ in any of the tissues in the grain filling region, suggesting that the role of $S$ rich proteins is insignificant with respect to $\mathrm{Zn}$ unloading from the maternal tissues (Fig. S1).

\section{Internal Zn transfer}

Another putative bottleneck for endosperm enrichment is the transfer of $\mathrm{Zn}$ from the aleurone cells into the subaleurone and starchy endosperm. In all cereals, the $\mathrm{Zn}$-concentration gradient between aleurone and endosperm is very steep (Liang et al., 2008; Hansen et al., 2009, 2012; Persson etal., 2009; Lombi et al., 2011), which in theory would make $\mathrm{Zn}$ transfer easy if it was a matter of simple diffusion. However, once inside the aleurone cells, $\mathrm{Zn}$ may be loaded into the vacuoles by transporters such as ZIF1, CAX1a or VIT1_2 (Becher et al., 2004; Tauris et al., 2009). Zn inside aleurone cells may also be scavenged by a range of insoluble ligands, including proteins and phytic acid. The transfer from aleurone to endosperm is still largely unknown, but expression of YSL9 in the barley endosperm
(Tauris et al., 2009) may indicate a role for NA in this transfer process. Certainly, changes in the total amount of endosperm proteins (e.g. through $\mathrm{N}$ fertilization) will affect the pool size and activity of ligands (e.g. NA and proteins) and transporters with a corresponding impact on transfer of $\mathrm{Zn}$ from aleurone into the endosperm.

The endosperm $\mathrm{Zn}$ concentrations measured after mechanical separation of grains showed a strong positive impact of $\mathrm{Zn}$ application (5.6 and 7.7 higher $\mathrm{Zn}$ concentration in HZn treatments compared with $\mathrm{LZn}$ at $\mathrm{LN}$ and $\mathrm{HN}$, respectively) as well as $\mathrm{N}$ application (63-90\% higher endosperm $\mathrm{Zn}$ concentration in the $\mathrm{HN}$ compared with the LN treatment at HZn and MZn, respectively; Table 1). The corresponding effects recorded based on the LA-ICP-MS images were less pronounced, showing only a threefold effect of $\mathrm{Zn}$ application and a $42-53 \%$ increase after $\mathrm{N}$ application (Fig. 2b). This apparent discrepancy between the results obtained by mechanical tissue separation and LA-ICP-MS likely reflects imperfect mechanical separation of the tissues, causing contamination of the endosperm with both bran and crease tissue material. In addition, the spike position may have an effect on the nutrient concentration of individual grains, which may contribute to the observed differences, because the mechanical separations included five grains against only one in the LA-ICP-MS analysis (Liu et al., 2006). Based on these observations, data obtained by mechanical tissue separation should be interpreted with great caution (Bityutskii et al., 2002). Nevertheless, the endosperm remaining after the mechanical removal of the bran still resembles the part of the grain that is actually consumed.

It has been suggested that a high $\mathrm{N}$ supply may drive the synthesis of NA and membrane-bound transport proteins, facilitating endosperm Zn loading (Cakmak et al., 2010b). However, this remains speculative. A high supply of $\mathrm{N}$ alone cannot enrich the grains with $\mathrm{Zn}$, as seen in Fig. 1 and Table S1, where it is also shown that the $\mathrm{HN}-\mathrm{LZn}$ has $c .80 \%$ higher $\mathrm{N}$ concentration than the $\mathrm{LN}-\mathrm{LZn}$, but with similar $\mathrm{Zn}$ concentration. This is in close agreement with previous findings (Kutman et al., 2010). Instead, upon endosperm loading, chelation of $\mathrm{Zn}$ is a necessity in order to prevent potentially toxic side reactions. Zinc acts as an electron acceptor, hence forming covalent bonds with $\mathrm{S}, \mathrm{N}$ and oxygen donors which are found mainly in cysteine (Cys), histidine (His), aspartic acid (Asn) and glutamic acid (Glu) (Broadley et al., 2007). The increased sulfur concentration in the $\mathrm{HN}-\mathrm{MZn}$ and $\mathrm{HN}-\mathrm{HZn}$ treatments suggests that certain $S$-containing, Cys-rich proteins are important for endosperm loading and storage of $\mathrm{Zn}$. During cultivation, the $\mathrm{MZn} / \mathrm{HZn}$ plants received more $S$ than the $\mathrm{LZn}$ plants (see the Materials and Methods section). However, the resulting increase in grain $S$ concentration in both the $\mathrm{HN}-\mathrm{MZn}$ and the $\mathrm{HN}-$ HZn was substantially higher than what could be deduced from differences in S-treatments, which underlines the synergism between $\mathrm{Zn}, \mathrm{N}$ and $\mathrm{S}$ enrichment. Increases in sulfate uptake by increasing $\mathrm{Zn}$ applications or increasing tissue $\mathrm{Zn}$ concentrations have been shown previously, supporting the findings in the present study (Coolong \& Randle, 2003; Stuiver etal., 2014). 


\section{Water-insoluble Zn}

The examined water-soluble fraction accounted for $22-26 \%$ of the total endosperm $\mathrm{Zn}$. The water-insoluble components of the endosperm, embracing $74-78 \%$ of the total endosperm $\mathrm{Zn}$, consist of ligands found in gluten proteins, starch and $\mathrm{InsP}_{6}$ complexes. Apart from the possibility of precipitated $\mathrm{InsP}_{6}: \mathrm{Zn}$ complexes, the water-insoluble fraction may of course also contain proteins which are crucial for efficient $\mathrm{Zn}$ loading and storage in the endosperm. He et al. (2013) showed that wheat grains have a decreasing total protein concentration towards the core endosperm. Such a gradient concurs with our LA-ICP-MS analysis, showing decreasing $S$ signals from the subaleurone towards the core endosperm (Fig. 3a,b). Along with the decreasing protein gradient, the protein composition also seems to change, the subaleurone being dominated by low molecular weight glutenin subunits (LMW-GS), $\alpha$ - and $\omega$-gliadins, whereas the core endosperm is rather dominated by high molecular weight glutenin subunits (HMW-GS) and $\gamma$-gliadins (He et al., 2013). Hence, because relatively more $\mathrm{Zn}$ accumulated in the core endosperm than in the subaleurone (Fig. 4), this suggests that a larger fraction of $\mathrm{Zn}$ in the insoluble fraction may be bound to HMW glutenin proteins and $\gamma$-gliadins, rather than to LMWGS and $\alpha$ - and $\omega$-gliadins.

\section{Zn storage and homeostasis}

In the speciation analysis, only the $\mathrm{Zn \# 2}$ fraction responded strongly to the combined $\mathrm{Zn} / \mathrm{N}$ treatments (Fig. $5 \mathrm{a}-\mathrm{c}$ ). This dynamic fraction was dominated by LMW defence proteins (alpha amylase inhibitors, related to pathogen defence) and proteins involved in stress and redox reactions, but only very few of these proteins have previously been assigned as $\mathrm{Zn}$-binding metalloproteins (Tables S4, S6). In this fraction, which ideally should only contain proteins with apparent masses from 10 to $30 \mathrm{kDa}$, we also found several proteins exceeding this range in molecular weights. This observation reflects one of the inherent weaknesses with SEC, as it does not measure size per se but rather the shape (the hydrodynamic cross-section) of proteins or proteincomplexes. Thus, structured or aggregated proteins appear larger than their true molecular mass whereas ionic or hydrophobic intractions with the stationary phase of the column will retain metalloproteins and lead to underestimation of molecular weights (Kirkwood et al., 2013). Therefore, accurate molecular weight estimations of the $\mathrm{Zn}$-binding proteins using SEC cannot be expected, as underlined by the LC-MS ${ }^{-2}$ based protein identifications in the $\mathrm{Zn \# 1}$ and $\mathrm{Zn \# 2}$ SEC fractions, which show that several proteins either appear smaller or larger than their true masses.

One of the best characterized $\mathrm{Zn}$-binding proteins in $\mathrm{Zn \# 2}$ is hydroxyacylgluthathione hydrolase, also known as glyoxalase II; which is a Cys-rich $29 \mathrm{kDa} \mathrm{Zn}$-binding enzyme, active in detoxification of the toxic metabolite methylglyoxal. Glyoxalase uses glutathione as a coenzyme for the conversion of toxic methylglyoxal to nontoxic D-lactic acid. It has been reported previously that overexpression of the glyoxalase system in Arabidopsis thaliana confers tolerance to high $\mathrm{Zn}$ concentrations (Singla-Pareek et al., 2006), and in barley grains it has been shown that glyoxalase II is present during all developmental stages (Finnie et al., 2002).

Another candidate is protein disulphide isomerase (PDI), a $56 \mathrm{kDa}$ protein which has been reported as $\mathrm{Zn}$ binding (Solovyov $\&$ Gilbert, 2004), and was reported to be upregulated in the $\mathrm{Zn}$ hyperaccumulators Noccaea caerulescens (Schneider et al., 2013) and $A$. halleri (Talke et al., 2006). Enolase ( $48.6 \mathrm{kDa})$ and chitinase $(28 \mathrm{kDa})$ have also been reported as $\mathrm{Zn}$ binding, but this is not well documented (Lebioda et al., 1991; Taylor et al., 1996).

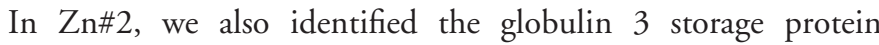
$(66 \mathrm{kDa})$, which belongs to the Cupin 1 superfamily. This protein putatively binds Zn (Shu et al., 2008); however, further experimental documentation of this process is needed.

Many of the redox active proteins in $\mathrm{Zn \# 2}$ may exert an influence on $\mathrm{Zn}$ binding via their cysteine groups (Giles et al., 2003; Broadley et al., 2007; Maret \& Krezel, 2007). Many of these proteins have been reported to confer the ability to release tightly bound $\mathrm{Zn}$ from metallothioneins (MTs) or from other Znbinding proteins (Maret \& Krezel, 2007). No MTs were identified in the current study, nor in other proteomic studies of wheat endosperm (Vensel etal., 2005), and hence their role in $\mathrm{Zn}$ homeostasis in the endosperm remains elusive (Tauris et al., 2009; Husted et al., 2011; Hegelund et al., 2012). Nevertheless, the increase of $S$ in the $Z n \# 2$ fraction, together with the changes in $\mathrm{Zn} / \mathrm{S}$ ratios, may indicate that some $\mathrm{Zn}$-related stress/redox proteins are important for the higher $Z n$-binding capacity seen in the $\mathrm{HN}-\mathrm{HZn}$ and $\mathrm{HN}-\mathrm{MZn}$ treatments. Whether or not these proteins in fact act as transient $\mathrm{Zn}$-binding proteins or if they simply appear as a response to $\mathrm{Zn}$-related oxidative stress cannot be concluded here, because none of them have yet been isolated and tested for their individual $\mathrm{Zn}$-binding features. Also their respective quantitative role in $\mathrm{Zn}$ speciation deserves further investigation.

The results of this study indicate a critical role of $\mathrm{N}$ and $\mathrm{S}$ nutrition in deposition and speciation of $\mathrm{Zn}$ in the endosperm of durum wheat. The findings presented will be highly useful in designing breeding programmes and in creating genetically engineered plants aimed for improving endosperm $\mathrm{Zn}$ concentrations in cereals.

\section{Acknowledgements}

We thank Thomas Hesselhøj Hansen and Lena Byrgesen for their excellent technical assistance. This work was supported financially by the Danish Council for Independent Research Technology and Production Sciences (FTP), projects 10-100087 and 10082111 (Sapere Aude) and the Danish Council for Independent Research - Nature and Universe, project: DFF - 4002-00181.

\section{Author contributions}

D.P.P., U.B.K, I.C., J.K.S. and S.H. planned the research. Plant cultivation, collection of agronomic data and total element analyses were done by U.B.K. and I.C. D.P.P. performed the tissue separation and analysed the samples. D.P.P., P.R.P. and T.C.dB. 
performed and interpreted the LA-ICP-MS analyses. D.P.P. and S.H. performed and interpreted the LC-ICP-MS analyses. B.A., C.F., S.H. and D.P.P. analysed and interpreted the proteomics data. D.P.P, S.H. and J.K.S. wrote the manuscript with contributions from all co-authors.

\section{References}

Aciksoz SB, Yazici A, Ozturk L, Cakmak I. 2011. Biofortification of wheat with iron through soil and foliar application of nitrogen and iron fertilizers. Plant and Soil 349: 215-225.

Ajiboye B, Cakmak I, Paterson D, de Jonge MD, Howard DL, Stacey SP, Torun AA, Aydin N, McLaughlin MJ. 2015. X-ray fluorescence microscopy of zinc localization in wheat grains biofortified through foliar zinc applications at different growth stages under field conditions. Plant and Soil 392: 357-370.

Becher M, Talke IN, Krall L, Kramer U. 2004. Cross-species microarray transcript profiling reveals high constitutive expression of metal homeostasis genes in shoots of the zinc hyperaccumulator Arabidopsis halleri. Plant Journal 37: 251-268.

Becker JS, Dietrich RC, Matusch A, Pozebon D, Dressier VL. 2008. Quantitative images of metals in plant tissues measured by laser ablation inductively coupled plasma mass spectrometry. Spectrochimica Acta Part BAtomic Spectroscopy 63: 1248-1252.

Bityutskii NP, Magnitskiy SV, Korobeynikova LP, Lukina EI, Soloviova AN, Patsevitch VG, Lapshina IN, Matveeva GV. 2002. Distribution of iron, manganese, and zinc in mature grain and their mobilization during germination and early seedling development in maize. Journal of Plant Nutrition 25: 635-653.

Bouis HE, Welch RM. 2010. Biofortification-A sustainable agricultural strategy for reducing micronutrient malnutrition in the global south. Crop Science 50: S20-S32.

Broadley MR, White PJ, Hammond JP, Zelko I, Lux A. 2007. Zinc in plants. New Phytologist 173: 677-702.

Cakmak I, Kalayci M, Kaya Y, Torun AA, Aydin N, Wang Y, Arisoy Z, Erdem $\mathrm{H}$, Yazici A, Gokmen O et al. 2010a. Biofortification and localization of zinc in wheat grain. Journal of Agricultural and Food Chemistry 58: 9092-9102.

Cakmak I, Pfeiffer WH, McClafferty B. 2010b. Biofortification of durum wheat with zinc and iron. Cereal Chemistry 87: 10-20.

Coolong TW, Randle WM. 2003. Zinc concentration in hydroponic solution culture influences zinc and sulfur accumulation in Brassica rapa $\mathrm{L}$. Journal of Plant Nutrition 26: 949-959.

DuPont FM, Chan R, Lopez R, Vensel WH. 2005. Sequential extraction and quantitative recovery of gliadins, glutenins, and other proteins from small samples of wheat flour. Journal of Agricultural and Food Chemistry 53: 1575-1584.

Emanuelsson O, Nielsen H, Brunak S, von Heijne G. 2000. Predicting subcellular localization of proteins based on their $\mathrm{N}$-terminal amino acid sequence. Journal of Molecular Biology 300: 1005-1016.

Finnie C, Melchior S, Roepstorff P, Svensson B. 2002. Proteome analysis of grain filling and seed maturation in barley. Plant Physiology 129: 1308-1319.

Garcia-Banuelos ML, Sida-Arreola JP, Sanchez E. 2014. Biofortification promising approach to increasing the content of iron and zinc in staple food crops. Journal of Elementology 19: 865-888.

Gibson RS. 2012. Zinc deficiency and human health: etiology, health consequences, and future solutions. Plant and Soil 361: 291-299.

Gibson RS, Bailey KB, Gibbs M, Ferguson EL. 2010. A review of phytate, iron, zinc, and calcium concentrations in plant-based complementary foods used in low-income countries and implications for bioavailability. Food and Nutrition Bulletin 31: S134-S146.

Gibson RS, Hess SY, Hotz C, Brown KH. 2008. Indicators of zinc status at the population level: a review of the evidence. British Journal of Nutrition 99: S14S23.

Giles NM, Watts AB, Giles GI, Fry FH, Littlechild JA, Jacob C. 2003. Metal and redox modulation of cysteine protein function. Chemistry \& Biology 10: $677-693$
Hansen TH, Laursen KH, Persson DP, Pedas P, Husted S, Schjoerring JK. 2009. Micro-scaled high-throughput digestion of plant tissue samples for multi-elemental analysis. Plant Methods 5: 12.

Hansen TH, Lombi E, Fitzgerald M, Laursen KH, Frydenvang J, Husted S, Boualaphanh C, Resurreccion A, Howard DL, de Jonge MD et al. 2012. Losses of essential mineral nutrients by polishing of rice differ among genotypes due to contrasting grain hardness and mineral distribution. Journal of Cereal Science 56: 307-315.

He JB, Penson S, Powers SJ, Hawes C, Shewry PR, Tosi P. 2013. Spatial patterns of gluten protein and polymer distribution in wheat grain. Journal of Agricultural and Food Chemistry 61: 6207-6215.

Hegelund JN, Schiller M, Kichey T, Hansen TH, Pedas P, Husted S, Schjoerring JK. 2012. Barley metallothioneins: MT3 and MT4 are localized in the grain aleurone layer and show differential zinc binding. Plant Physiology 159: 1125-1137.

Hotz C, Brown KH. 2001. Identifying populations at risk of zinc deficiency: the use of supplementation trials. Nutrition Reviews 59: 80-84.

Hunt JR. 2003. Bioavailability of iron, zinc, and other trace minerals from vegetarian diets. American Journal of Clinical Nutrition 78: 633s-639s.

Husted S, Persson DP, Laursen KH, Hansen TH, Pedas P, Schiller M, Hegelund JN, Schjoerring JK. 2011. The role of atomic spectrometry in plant science. Journal of Analytical Atomic Spectrometry 26: 52-79.

Kirkwood KJ, Ahmad Y, Larance M, Lamond AI. 2013. Characterization of native protein complexes and protein isoform variation using sizefractionation-based quantitative proteomics. Molecular \& Cellular Proteomics 12: 3851-3873.

Kutman UB, Yildiz B, Cakmak I. 2011. Improved nitrogen status enhances zinc and iron concentrations both in the whole grain and the endosperm fraction of wheat. Journal of Cereal Science 53: 118-125.

Kutman UB, Yildiz B, Ozturk L, Cakmak I. 2010. Biofortification of durum wheat with zinc through soil and foliar applications of nitrogen. Cereal Chemistry 87: 1-9.

Kyriacou B, Moore KL, Paterson D, de Jonge MD, Howard DL, Stangoulis J, Tester M, Lombi E, Johnson AAT. 2014. Localization of iron in rice grain using synchrotron X-ray fluorescence microscopy and high resolution secondary ion mass spectrometry. Journal of Cereal Science 59: 173-180.

Lebioda L, Stec B, Brewer JM, Tykarska E. 1991. Inhibition of enolase - the crystal-structures of enolase- $\mathrm{Ca}^{2+}-2$-phosphoglycerate and enolase- $\mathrm{Zn}^{2+}$ phosphoglycolate complexes at 2.2-A resolution. Biochemistry 30: 2823-2827.

Lee S, Jeon US, Lee SJ, Kim YK, Persson DP, Husted S, Schjorring JK, Kakei Y, Masuda H, Nishizawa NK et al. 2009. Iron fortification of rice seeds through activation of the nicotianamine synthase gene. Proceedings of the National Academy of Sciences, USA 106: 22014-22019.

Lee S, Persson DP, Hansen TH, Husted S, Schjoerring JK, Kim YS, Jeon US, Kim YK, Kakei Y, Masuda H et al. 2011. Bio-available zinc in rice seeds is increased by activation tagging of nicotianamine synthase. Plant Biotechnology Journal 9: 865-873.

Liang H, Li Z, Tsuji K, Nakano K, Nout MR, Hamer RJ. 2008. Milling characteristics and distribution of phytic acid and zinc in long-, medium- and short-grain rice. Journal of Cereal Science 48: 83-91.

Liu ZH, Wang HY, Wang XE, Zhang GP, Chen PD, Liu DJ. 2006. Genotypic and spike positional difference in grain phytase activity, phytate, inorganic phosphorus, iron, and zinc contents in wheat (Triticum aestivum L.). Journal of Cereal Science 44: 212-219.

Lombi E, Smith E, Hansen TH, Paterson D, de Jonge MD, Howard DL, Persson DP, Husted S, Ryan C, Schjoerring JK. 2011. Megapixel imaging of (micro)nutrients in mature barley grains. Journal of Experimental Botany 62: 273-282.

Lonnerdal B, Bryant A, Liu XF, Theil EC. 2006. Iron absorption from soybean ferritin in nonanemic women. American Journal of Clinical Nutrition 83: 103-107.

Lott JNA, Ockenden I, Raboy V, Batten GD. 2000. Phytic acid and phosphorus in crop seeds and fruits: a global estimate. Seed Science Research 10: 11-33.

Maret W, Krezel A. 2007. Cellular zinc and redox buffering capacity of metallthionein/thionein in health and disease. Molecular Medicine 13: $371-375$. 
Moore KL, Zhao FJ, Gritsch CS, Tosi P, Hawkesford MJ, McGrath SP, Shewry PR, Grovenor CRM. 2012. Localisation of iron in wheat grain using high resolution secondary ion mass spectrometry. Journal of Cereal Science 55: 183-187.

Neal AL, Geraki K, Borg S, Quinn P, Mosselmans JF, Brinch-Pedersen H, Shewry PR. 2013. Iron and zinc complexation in wild-type and ferritinexpressing wheat grain: implications for mineral transport into developing grain. Journal of Biological Inorganic Chemistry 18: 557-570.

Pearson JN, Rengel Z, Jenner CF, Graham RD. 1996. Manipulation of xylem transport affects $\mathrm{Zn}$ and $\mathrm{Mn}$ transport into developing wheat grains of cultured ears. Physiologia Plantarum 98: 229-234.

Persson DP, Hansen TH, Laursen KH, Schjoerring JK, Husted S. 2009. Simultaneous iron, zinc, sulfur and phosphorus speciation analysis of barley grain tissues using SEC-ICP-MS and IP-ICP-MS. Metallomics 1: 418-426.

Schneider T, Persson DP, Husted S, Schellenberg M, Gehrig P, Lee Y, Martinoia E, Schjoerring JK, Meyer S. 2013. A proteomics approach to investigate the process of $\mathrm{Zn}$ hyperaccumulation in Noccaea caerulescens (J \& C. Presl) F.K. Meyer. Plant Journal 73: 131-142.

Shu NJ, Zhou TP, Hovmoller S. 2008. Prediction of zinc-binding sites in proteins from sequence. Bioinformatics 24: 775-782.

Singla-Pareek SL, Yadav SK, Pareek A, Reddy MK, Sopory SK. 2006. Transgenic tobacco overexpressing glyoxalase pathway enzymes grow and set viable seeds in zinc-spiked soils. Plant Physiology 140: 613-623.

Solovyov A, Gilbert HF. 2004. Zinc-dependent dimerization of the folding catalyst, protein disulfide isomerase. Protein Science 13: 1902-1907.

Stuiver CEE, Posthumus FS, Parmar S, Shahbaz M, Hawkesford MJ, De Kok LJ. 2014. Zinc exposure has differential effects on uptake and metabolism of sulfur and nitrogen in Chinese cabbage. Journal of Plant Nutrition and Soil Science 177: 748-757.

Talke IN, Hanikenne M, Kramer U. 2006. Zinc-dependent global transcriptional control, transcriptional deregulation, and higher gene copy number for genes in metal homeostasis of the hyperaccumulator Arabidopsis halleri. Plant Physiology 142: 148-167.

Tauris B, Borg S, Gregersen PL, Holm PB. 2009. A roadmap for zinc trafficking in the developing barley grain based on laser capture microdissection and gene expression profiling. Journal of Experimental Botany 60: 1333-1347.

Taylor KC, Albrigo LG, Chase CD. 1996. Purification of a Zn-binding phloem protein with sequence identity to chitin-binding proteins. Plant Physiology 110 : 657-664.

Velu G, Ortiz-Monasterio I, Cakmak I, Hao Y, Singh RP. 2014. Biofortification strategies to increase grain zinc and iron concentrations in wheat. Journal of Cereal Science 59: 365-372.

Vensel WH, Tanaka CK, Cai N, Wong JH, Buchanan BB, Hurkman WJ. 2005. Developmental changes in the metabolic protein profiles of wheat endosperm. Proteomics 5: 1594-1611.

Wang YX, Specht A, Horst WJ. 2011. Stable isotope labelling and zinc distribution in grains studied by laser ablation ICP-MS in an ear culture system reveals zinc transport barriers during grain filling in wheat. New Phytologist 189 428-437.

White PJ, Broadley MR. 2011. Physiological limits to zinc biofortification of edible crops. Frontiers in Plant Science 2: 1-11.
Wirth J, Poletti S, Aeschlimann B, Yakandawala N, Drosse B, Osorio S, Tohge T, Fernie AR, Gunther D, Gruissem W et al. 2009. Rice endosperm iron biofortification by targeted and synergistic action of nicotianamine synthase and ferritin. Plant Biotechnology Journal 7: 631-644.

Zhao FJ, Su YH, Dunham SJ, Rakszegi M, Bedo Z, McGrath SP, Shewry PR. 2009. Variation in mineral micronutrient concentrations in grain of wheat lines of diverse origin. Journal of Cereal Science 49: 290-295.

Zheng LQ, Cheng ZQ, Ai CX, Jiang XH, Bei XS, Zheng Y, Glahn RP, Welch RM, Miller DD, Lei XG et al. 2010. Nicotianamine, a novel enhancer of rice iron bioavailability to humans. PLoS ONE 5: e10190.

\section{Supporting Information}

Additional Supporting Information may be found online in the supporting information tab for this article:

Fig. S1 The images represent the crease regions in each of the six $\mathrm{Zn} / \mathrm{N}$ treatments, based on the same dataset used in Figs 2 and 3.

Table S1 Agronomic performance of durum wheat plants supplied with different combinations of $\mathrm{Zn}$ and $\mathrm{N}$

Table S2 Concentration of $\mathrm{N}$ and P in durum wheat grains harvested from plants supplied with different combinations of $\mathrm{Zn}$ and $\mathrm{N}$

Table S3 All of the identified proteins in the $\mathrm{Zn \# 1} \mathrm{fraction,} \mathrm{cor-}$ responding to molecular weights $50-100 \mathrm{kDa}$, collected in the SEC-ICP-MS analysis

Table S4 All of the identified proteins in the $\mathrm{Zn \# 2}$ fraction, corresponding to molecular weights $10-30 \mathrm{kDa}$, collected in the SEC-ICP-MS analysis

Table S5 Zn-related proteins in the $\mathrm{Zn \# 1} \mathrm{fraction,} \mathrm{collected}$ from the SEC-ICP-MS analysis

Table S6 Zn-related proteins in the $\mathrm{Zn \# 2}$ fraction, collected from the SEC-ICP-MS analysis

Please note: Wiley Blackwell are not responsible for the content or functionality of any supporting information supplied by the authors. Any queries (other than missing material) should be directed to the New Phytologist Central Office. 